\title{
PEMBENTUKAN KARAKTER RELIGIUS DI MADRASAH IBTIDAIYAH BERBASIS PESANTREN
}

\author{
Awaliyani Mahmudiyah \\ STAI Al-Azhar Menganti Gresik \\ awaliyanimahmudiah@gmail.com
}

\section{Mulyadi}

STAI Al-Azhar Menganti Gresik

Mulyadi091265@gmail.com

\begin{abstract}
Madrasah Ibtidaiyah Miftahul Ulum Kesamben Wetan. This study uses a qualitative research method with a case study approach. Data collection techniques using observation, interviews, and documentation. The data analysis technique used the analysis of Miles and Huberman. Test the validity of the data by triangulation and reference adequacy. The results of the research show that the process of building religious character in Islamic elementary schools based on the Miftahul Ulum Kesamben Wetan Islamic Boarding School through dhuha prayer, tahfidzul qur'an, congregational prayer, courtesy, through religious activities such as Eid al-fitr, Eid al adha, sharing zakat, sharing takji, and break fast together. Read the yasin letter every Friday, share on Friday legi, read juz amma', memorize daily prayers, and do active pesantren activities. The obstacle is synchronizing the vision and mission of the school with what parents expect, there are still children who arrive late, teachers are expected to be more careful in guiding children and providing good examples, children's abilities during the learning process, and children do not want to follow orders from teacher.
\end{abstract}

Keyword: Formation, Religious Character.

\begin{abstract}
Abstrak
Madrasah Ibtidaiyah Miftahul Ulum Kesamben Wetan. Penelitian ini menggunakan metode penelitian kualitatif dengan pendekatan studi kasus. Teknik pengumpulan data menggunakan observasi, wawancara, dan dokumentasi. Teknik analisis data menggunakan analisis Miles dan Huberman. Uji keabsahan data dengan triangulasi dan kecukupan referensi. Adapun hasil penelitian menunjukkan bahwa proses pembentukan karakter religius di Madrasah Ibtidaiyah Berbasis Pesantren Miftahul Ulum Kesamben wetan melalui kegiatan sholat dhuha, tahfidzul qur'an, sholat berjamaah, sopan santun, melalui kegiatan keagamaan seperti Idul fitri, Idul adha, berbagi zakat, berbagi takji, dan buka bersama. Membaca surat yasin setiap hari jum 'at, berbagi di hari jum 'at legi, membaca juz amma', hafalan do'a sehari-hari, dan kegiatan giat pesantren. Kendalanya yaitu mensinkronkan visi dan misi sekolah dengan yang diharapkan orang tua, masih terdapat anak yang datang terlambat, guru diharapkan lebih telaten dalam membimbing anak dan memberikan contoh yang baik, kemampuan anak-anak ketika proses pembelajaran, dan anak-anak tidak mau mengikuti perintah dari guru.
\end{abstract}

Kata Kunci: Pembentukan, Karakter Religius.

Program Studi Pendidikan Guru Madrasah Ibtidaiyah

STAI Al-Azhar Menganti Gresik, Indonesia

\section{Pendahuluan}

Dalam bahasa Arab, karakter memiliki makna yang hampir sama dengan akhlak, yang berarti tindakan yang mencerminkan jati diri seseorang. Al-Ghazali mengilustrasikan bahwa akhlak adalah perbuatan baik yang berasal dari hati. Sedangkan, Lickona memandang karakter sebagai suatu watak dalam menanggapi situasi dengan cara yang terbaik dan tindakan yang bermoral. Lickona juga berpendapat bahwa karakter terdiri dari tiga bagian 
ZAHRA: Research And Tought Elmentary School Of Islam Journal Vol. (2) (1), (Bulan)(Tahun), (Halaman)(55-72)| 56 yang saling berkaitan, yang meliputi pengetahuan akan moral, perasaan, dan perilaku bermoral (Dian, 2019).

Berdasarkan definisi tentang karakter di atas, penulis mendefinisikan karakter sebagai sikap yang mencerminkan pribadi seseorang dalam bertingkah laku, berbicara, berpakaian, juga beribadah kepada Allah. Dari konsep karakter muncullah sebuah konsep tentang pendidikan karakter. Pendidikan karakter merupakan salah satu usaha yang dapat dilakukan dalam membentuk kebiasaan baik pada setiap individu, utamanya pada anak-anak, sehingga karakter baik pada anak dapat tertanam sejak dini.

Konsep pendidikan karakter sebenarnya telah dikenalkan sejak tahun 1900-an. Thomas Lickona merupakan salah satu tokoh yang dianggap mempopulerkan konsep ini, terutama pada saat Lickona menuliskan bukunya yang berjudul Eduacation for Character: How Our School Can Teach Respect and Renponsibility. Melalui karyanya, Lickona berhasil menginformasikan pada dunia tentang pentingnya pendidikan karakter. Menurut Lickona, pendidikan karakter memiliki tiga aspek penting yaitu, mengetahui, mencintai dan melakukan kebaikan.

Ratna Meagawangi mendefinisikan pendidikan karakter sebagai sebuah usaha untuk membimbing anak-anak dalam menyelesaikan masalah dengan baik dan menerapkannya dalam kehidupan sehari-hari baik pada lingkungan keluarga, sekolah, dan masyarakat. Fakry Gaffar juga mengemukakan definisi tentang pendidikan karakter, menurutnya pendidikan karakter adalah suatu proses untuk mentransfer nilai-nilai kehidupan agar dapat ditumbuhkembangkan oleh seseorang dalam bertingkah laku sehari-hari. Dari kedua definisi tentang pendidikan karakter yang telah disebutkan, terdapat 3 poin penting yakni: 1) proses untuk mentransfer nilai-nilai, 2) ditumbuhkembangkan dalam kepribadian, dan 3) menjadi suatu kesatuan dalam perilaku (Kesuma, 2018).

(Marzuki, 2015) Pendidikan karakter memiliki beberapa tujuan antara lain yaitu memberikan pelayanan akan penguatan dan pengembangan nilai-nilai yang dapat memperbaiki perilaku anak, baik ketika anak tersebut berada dalam maupun luar lingkungan sekolah, mengkoreksi tingkah laku siswa yang tidak sesuai dengan nilai-nilai karakter yang diharapkan, serta membangun hubungan yang baik antara keluarga dan masyarakat dalam mengembangkan pendidikan karakter.

Nilai-nilai karakter yang perlu ditanamkan pada anak adalah nilai universal yang meliputi nilai agama, moral, kewarganegaraan, adat istiadat, budaya, hukum, dll. Sebab nilainilai tersebut sangat mudah diterima oleh seluruh golongan masyarakat, sehingga mampu 
ZAHRA: Research And Tought Elmentary School Of Islam Journal Vol. (2) (1), (Bulan)(Tahun), (Halaman)(55-72)| 57 mempersatukan bangsa yang beraneka ragam budaya, agama, ras, adat istiadat, suku, dan latar belakang.

Sedangkan pendidikan karakter memiliki sembilan pilar yang merupakan nilai-nilai universal, diantaranya yaitu mencintai Tuhan dan seluruh ciptaan-Nya, mandiri dan tanggung jawab, jujur atau amanah, bersikap hormat dan santun, dermawan, gotong royong dan suka menolong (Uswatun, 2011). Pendidikan karakter merupakan suatu hal yang perlu ditanamkan pada anak sejak dini, terutama pada anak usia sekolah dasar. Menurut Kemendiknas, terdapat 18 nilai pendidikan karakter yang harus ditanamkan pada siswa sekolah dasar dan menengah antara lain, religius, toleransi, jujur, kerja keras, disiplin, mandiri, kreatif, demokratis, nasionalis, rasa ingin tahu, cinta tanah air, bersahabat, menghargai prestasi, cinta damai, peduli lingkungan, gemar membaca, tanggung jawab, dan peduli sosial.

Dalam penelitiannya, David dan lainnya menyatakan bahwa karakter yang paling ditekankan dalam penanaman karakter peserta didik adalah karakter religius, jujur, dan toleransi karena ketiga karakter tersebut sudah mewakili 15 karakter yang lainnya dan yang paling berhubungan erat dengan keseharian siswa. Religius merupakan nilai yang berhubungan dengan Tuhan.

Religius berasal dari bahasa asing yang berarti agama. Frezer mendefinisikan agama adalah suatu kepercayaan yang selalu mengalami perubahan dan perkembangan sesuai dengan tingkat keyakinan seseorang. Sedangkan Jalaluddin dalam bukunya menyatakan bahwa agama mempunyai arti percaya kepada Tuhan sebagai pencipta dan pemelihara alam semesta, berupa rutinitas ibadah, dan suatu kondisi jiwa atau cara hidup yang mencerminkan cinta terhadap Tuhan, serta berperilaku sesuai dengan aturan Tuhan. Dapat diketahui bahwa religius adalah suatu sikap yang tertanam dalam pribadi seseorang dalam memeluk dan menjalankan ajaran agama yang dianutnya serta mengaplikasikannya dalam kehidupan sehari-hari sebagai bentuk iman dan taqwa kepada Tuhan (Huda, 2019).

Dalam menghadapi perubahan zaman dan kemorosotan moral di kalangan pelajar saat ini, karakter religius sangat perlu untuk dikembangkan pada lembaga pendidikan, terutama pada pendidikan dasar. (Hambali: 193-208) Untuk mewujudkan harapan tersebut dibutuhkan tenaga pendidik yang mampu menjadi teladan bagi siswa. Proses pembentukan karakter religius tidak akan terlaksana jika pendidik hanya sebatas memberikan perintah pada siswa untuk melaksanakan ajaran agama, akan tetapi seorang pendidik harus mampu memberikan contoh agar dapat dijadikan teladan bagi peserta didik. Dengan cara tersebut, siswa akan lebih mudah mengikuti perilaku yang baik dari gurunya, sehingga proses pembentukan karakter religius akan berjalan lebih efektif. 
ZAHRA: Research And Tought Elmentary School Of Islam Journal Vol. (2) (1), (Bulan)(Tahun), (Halaman)(55-72)| 58

Berpadunya budaya pesantren dengan manajemen sekolah pada sekolah berbasis pesantren, ditujukan sebagai usaha dalam proses menyatukan antara manajemen sekolah dengan nilai-nilai agama dan budaya pesantren. Serta kebijakan pendidikan nasional yang benar-benar ada dalam setiap tindakan pengelolaan pendidikan di lingkungan pondok pesantren. Dengan adanya konsep sekolah berbasis pesantren, terdapat perpaduan budaya pesantren ke dalam pembelajaran dan manajemen sekolah. Namun, dalam pelaksanaannya tentu tidak akan terlepas dari beberapa metode dan kendala (Nasrullah, 2017).

Pendidikan karakter yang dikembangkan di pesantren lebih fokus pada aspek religius, akhlakul karimah, kesederhanaan, disiplin, dan pemahaman tentang makna hidup. Sedangkan pada lembaga pendidikan formal siswa lebih ditekankan pada pengetahuan umum seperti ilmu pengetahuan alam, sastra, budaya, dan teknologi dengan kurikulum yang sudah tertata dengan baik dan sumber daya manusia yang mumpuni. Melalui proses perpaduan yang ada, kedepannya siswa diharapkan mampu menjadi pribadi yang unggul baik dari segi spiritual, intelektual, dan sosial.

Penjelasan tentang pendidikan karakter religius diatas searah dengan beberapa hasil penelitian yang berupa skripsi maupun artikel yang dimuat dalam jurnal, seperti penelitian yang dilakukan oleh Tsalis Nurul 'Azizah dengan judul "Pembentukan Karakter Religius Berbasis Pembiasaan dan Keteladanan di SMA Al-Qur'an Wahid Hasyim Yogyakarta, terbukti bahwa pembentukan karakter religius berbasis pembiasaan dan keteladanan di SMA Sains Al-Qur'an, telah berhasil membentuk beberapa karakter religius pada siswa seperti kedisiplinan, rajin mengaji Al-Qur'an, saling menghormati, peduli lingkungan dan taat pada peraturan sekolah (Nurul, 2017).

Penelitian dari Happy Makrufiati Rosyidah dengan judul "Strategi Pembentukan Karakter Religius Melalui Program Madrasah Taklimiyah di SMP Islam Hasanudin Kesamben Kabupaten Blitar, membutikan bahwa strategi yang digunakan dalam membentuk karakter religius melalui program madrasah diniyah taklimiyah yaitu: a) Pemberian materi, yang meliputi berdo'a, hafalan do'a dan surah pendek, motivasi guru, praktik sholat, membaca dan menulis Al-Qur'an. b) memberikan contoh yang baik, memakai baju yang rapi dan sopan, berbicara dan bertingkah laku yang sopan santun, memberikan contoh tata cara sholat, dan mengaji. c) pembiasaan gerakan $3 \mathrm{~S}$ (senyum, salam, dan sapa), sholat dhuha dan dhuhur berjamaah, istighosah, beramal, khotmil Qur'an, hafalan do'a dan bacaan sholat, serta surat-surat pendek (Rosyidah, 2019).

Sejalan dengan beberapa penelitian diatas, Miftahul Jannah juga mempunyai hasil penelitian tentang "Model dan Strategi Pembentukan Karakter Religius yang di Terapkan di 
ZAHRA: Research And Tought Elmentary School Of Islam Journal Vol. (2) (1), (Bulan)(Tahun), (Halaman)(55-72)| 59 SDTQ-T An-Najah Pondok Pesantren Cindai Alus Martapura, membutikan bahwa metode pembentukan karakter religius yang di Terapkan di SDTQ-T An-Najah Pondok Pesantren Cindai Alus Martapura yaitu: (1) dengan cara memberikan contoh yang baik, (2) dengan cara pembiasaan, (3) dengan cara mengajak manusia dengan memberikan pembelajaran dan nasihat yang baik dan juga pengetahuan isi kandungan dari Al-Qur'an, (4) dengan cara pemberian hadiah dan hukuman. Sedangkan strategi pendidikan karakter religius siswa SDTQ-T An-Najah Pondok Pesantren Cindai Alus Martapura yaitu: (1) memberi tahu betapa pentingnya kesadaran dalam bidang ibadah dalam kehidupan sehari-hari, (2) melakukan teguran secara langsung dan juga memberikan contoh secara langsung kepada siswa, (3) contoh yang baik, (4) kegiatan yang tidak terencana, (5) teguran, (6) pengkondisian lingkungan, (7) kegiatan rutin, adan (8) disiplin yang tertata (Miftahul Jannah, 2019).

Madrasah Ibtidaiyah Miftahul Ulum Kesamben Wetan merupakan satu-satunya Madrasah Ibtidaiyah berbasis pesantren di desa Kesamben Wetan, Kecamatan Driyorejo Kabupaten Gresik. Madrasah ini telah terakreditasi "A”. Madrasah Ibtidaiyah Miftahul Ulum berada di bawah naungan Lembaga Pendidikan Ma'arif NU.(Arif \& Handayani, 2020) Walaupun madrasah ini tidak dikelola oleh yayasan yang memiliki pondok pesantren, namun Madrasah Ibtidiyah Miftahul Ulum Kesamben Wetan ini berani menyematkan label berbasis pesantren pada Madrasah Ibtidiyah Miftahul Ulum. Hal ini dikarenakan keinginan kepala madrasah dalam menanamkan jiwa pesantren kepada peserta didiknya dengan kurikulum gabungan antara kurikulum pesantren dengan kurikulum umum dari pemerintah. Madrasah Ibtidaiyah Miftahul Ulum Kesamben Wetan merupakan Madrasah Ibtidaiyah yang sangat maju. Terbukti dengan jumlah peserta didik yang setiap tahunnya mengalami peningkatan, selain itu madrasah ini juga sering meraih juara dari berbagai macam perlombaan. Madrasah Ibtidaiyah Miftahul Ulum dikenal karena sisi Al-Qur'an, pendidikan karakter dan akademiknya. (Yanus Setyowati, 2020) Pendidikan karakter untuk bidang religius yang diterapkan di Madrasah Ibtidiyah Miftahul Ulum tentang akhlakul karimah dan menggunakan pendeketan pesantren, dimana proses pembelajarannya seperti di pesantren misalnya, menanamkan jiwa pesantren melalaui kegiatan makan bersama, membiasakan sholat dhuha setiap hari, setiap jum'at anak-anak diajak membaca surat Yasin, mengajak anak-anak untuk kultum setelah selasai sholat dhuha dan anak-anak diajarkan untuk selalu disiplin dalam berbagai hal khususnya kegiatan beribadah. Pada penelitian ini menitik fokuskan pada proses pembentukan karakter religius siswa dan kendala dalam pembentukan karater siswa. 
ZAHRA: Research And Tought Elmentary School Of Islam Journal Vol. (2) (1), (Bulan)(Tahun), (Halaman)(55-72)| 60

\section{Metode Penelitian}

Penelitian ini menggunakan metode penelitian kualitatif. Dalam penelitian ini, peneliti menggunakan pendekatan studi kasus, dan menggunakan 2 jenis sumber data, yaitu sumber data primer dan sekunder. Dalam mengumpulkan data, peneliti melakukan observasi, wawancara, dan dokumentasi. Teknik analisis data yang digunakan yaitu teknik analisis data dari Miles dan Huberman. Dalam menguji keabsahan data, peneliti menggunakan triangulasi dan kecukupan referensi.

\section{Hasil Penelitian}

Dalam proses pembentukan karakter religius seorang guru tentunya membutuhkan strategi dalam penerapannya. Menurut SY selaku kepala sekolah, beliau mengatakan sebagai berikut: "Kami untuk membangun karakter yaitu berbasis keteladanan, jadi dalam membentuk karakter itu harus banyak aplikasi, contoh, teladan, tidak hanya sekedar materi maka disitu kami harus memunculkan kebiasaan yang mana kebiasaan yang dilakukan berulang-ulang akan jadi sebuah karakter. Melalui kebiasaan sholat dhuha, Tahfidzul Qur'an, sholat jamaah tepat waktu, pembiasan sopan santun atau akhlakul karimah. Langkah-langkah yang dilakukan melalui kegiatan awal masuk sekolah sudah kita peta mana anak-anak yang berangkat dari agamis dan anak-anak yang berangkat dari keluarga nasionalis. Kami memberikan pendekatan yang berbeda antara keluarga agamis dan nasionalis. Kalau anak-anak dari keluarga agamis maka kita lebih mudah untuk melakukan pendekatan, sedangkan anak-anak yang dari keluarga nasionalis kita melakukan pendekatannya agak susah, karena terkadang orang tuanya itu tidak mengerti apa yang kita harapkan sehingga akan terjadi misskomukasi. Seperti kita menghukum anak-anak yang terlambat sholat dhuha anak-anak dari keluarga agamis akan mendukung kegiatan tersebut berbeda dengan keluarga nasionalis yang terkadang menganggap hal tersebut malah memberi beban terhadap anak tersebut. Contohnya kita itu juga melacak dunia santri melalui sosmed, anak-anak yang fotonya tidak membawa pribadi yang religius seperti tik-tok, fotofoto yang tidak sopan anak-anak langsung dipanggil ke ruang kepala sekolah.

Karakter yang menonjol adalah kejujuran, kita tidak pernah mengajarkan anak-anak untuk meminta-minta, jadi anak-anak tidak pernah meminta apapun kepada teman-temanya, dan sopan santun mereka sudah tau adab terhadap gurunya. Terus yang paling penting anak-anak sudah terbangun kedewasaannya itu yang ingin kami jadikan pembeda dengan anak-anak dari madrasah lain. Kendalanya cuma mensinkronkan visi dan misi dengan orang tua yang dimau sekolah seperti ini, terkadang walimurid tidak memhami menganggap itu terlalu keras, terlalu berat bagi anak-anak seperti anak-anak yang Tahfidzul Qur'an padahal kita mengajarinya sistemnya tidak menyuruh untuk menghafalkan tetapi membiasakan akan terbawa dengan sendirinya. Untuk mengatasi kendalan tersebut kami setiap moment mengadakan parenting seperti kegiatan mengambil rapot disini kita tidak ingin walimurid hanya mengambil rapot saja disini harus ada do'a bersama, tausiyah, pencerahan dari dalam sekolah maupun dari luar sekolah terhadap para walimurid agar mereka memiliki persepsi yang 
ZAHRA: Research And Tought Elmentary School Of Islam Journal Vol. (2) (1), (Bulan)(Tahun), (Halaman)(55-72)| 61 sama. Apa yang diharapkan orang tua dan pihak sekolah bisa terlaksana dengan baik biar mereka tidak salah persepsi dengan apa yang dilakukan oleh sekolah.” (Sulistyono, 2020).

Menurut ibu SA selaku waka kurikulum, beliau mengatakan sebagai berikut: "Melalui program kegiatan keagamaan seperti Idul Fitri, Jum'at Berkah (membaca yasin), Idul Adha, berbagi zakat fitrah kepada fakir miskin di bulan puasa, anak-anak diajarkan berbagi pada hari Jum'at legi, bagi takjil di bulan puasa, dan buka puasa bersama. Langkah-langkah yang dilakukan dalam membentuk karakter religius melalui kegiatan pembiasaan untuk kelas bawah dan kelas atas seperti setiap pagi sholat dhuha setelah itu mengaji bersama, tetapi untuk kelas atas ada kegiatan giat pesantren yang dilaksanakan setelah sholat dhuhur. Karakter religius yang terbentuk mulai dari pembiasaan bersama teman-temannya, orang tua, dari sholat berjamaah setiap hari, memberi kepada orang yang tidak mampu. Untuk karakter yang paling menonjol adalah keagamaan. Tidak mengalami kendala karena mereka sudah terbiasa dalam hal-hal kegiatan keagamaan. Karena mereka lebih suka kalau diajak untuk melakukan kegiatan istighosah, tahlil, dan do;a bersama. Mungkin kendalanya pada anak kelas 1 kalau berangkatnya kesiangan tidak mau ikut sholat dhuha, kalau untuk yang lainnya tidak ada kendala. Cara mengatasinya dengan cara ketika melakukan kesalahan langsung dipanggil ke kantor agar masalah nya tidak berkelanjutan dengan menanyakan apa yang membuat anak tersebut melakukan kesalahan tersebut.” (Siska, 2020).

Menurut ibu YS selaku waka kesiswaan, beliau mengatakan sebagai berikut: "Menurut saya pembentukan karakter bisa dilakukan melalui kegiatan sholat dhuha setiap hari senin-kamis, hari jum'at membaca surat yasin bersama, dan melalui kegiatan yang lainnya seperti memperingati hari besar Islam. Langkah-langkah yang saya gunakan dalam membentuk karakter religius melalui proses pembiasaaan yang dilakukan sejak dini seperti sholat tepat waktu. Dan karakter yang terbentuk adalah akhlakul karimah, baik secara religius dengan pendidikan agama dan pendidikan umum. Tetapi kita lebih menitik beratkan pada pendidikan agama soalnya kita memang sekolah kita berbasis pesantren. Kendala yang saya hadapi dalam pembentukan karakter religius diantaranya lebih telaten pada anak kelas 1 dalam membimbing dan memberikan contoh yang baik kepadanya seperti guru datang lebih dulu ke masjid, menata sandal ketika sampai di masjid, menata shaf-shaf ketika sholat, dan menuntun anak-anak dalam membaca bacaan sholat agar terbiasa membaca bacaan sholat. Cara mengatasinya dengan memberikan contoh yang baik kepada anak-anak, guru tidak hanya memerintah saja tapi juga mengasih contoh." Menurut ibu SW selaku guru kelas 6, beliau mengatakan sebagai berikut: "Melalui program sholat dhuha, membaca yasin berjamaah (Jum'at Berkah), anak-anak diajarkan berbagi di hari jum'at legi. Langkah-langkah yang dilakukan dalam membentuk karakter religius seperti mendapatkan pelajaran dari kepala sekolah, melalui proses pembelajaran, dll. Karakter religius yang sudah terbentuk selama ini seperti sopan, disiplin, dan rapi. Tetapi lebih menonjol di karakter disiplin yang ada dalam diri anak-anak. Kendalanya yang dihadapi dalam pembentukan karakter religius diantaranya dalam penentuan kelas yang dimana terdapat kelas yang unggul, super unggul, rendah dan tengah-tengah dari segi SDM dan dari kemampuan anak-anak. Cara mengatasinya dengan terus 
ZAHRA: Research And Tought Elmentary School Of Islam Journal Vol. (2) (1), (Bulan)(Tahun), (Halaman)(55-72)| 62 bersabar dan memberikan arahan yang baik kepada anak-anak.” (Yanus, 2020). Dan menurut ibu DR selaku guru kelas 1, beliau mengatakan sebagai berikut: "Melalui kegiatan giat pesantren setiap pagi, sebelum memulai pelajaran membaca juz amma', sholat dhuha berjamaah, hafalan do'a sehari-hari dan do'a-do'a sholat, biasanya kalau pulangnya jam 12 melakukan sholat dhuhur berjamaah untuk kelas 1 \& 2 kalau kelas 3-6 melaksanakan sholat ashar berjamaah disekolah. Langkah-langkah yang dilakukan dengan membiasakan sholat berjamaah, mengucapkan salam, memberi salam saat bertemu gurunya baik di dalam maupun luar sekolah. Karakter religius yang sudah terbentuk melalui proses pembiasaan ketika mau makan langsung berdo'a sendiri, setelah makan selalu berdo'a, ketika mau pulang selalu berdo'a tanpa disuruh, ketika mendengar adzan langsung menuju masjid. Ketika anakanak disuruh berdo'a tanpa harus disuruh berdo'a tetapi lewat sentuhan yang akan membuat anakanak mempunyai inisiatif untuk berdo'a sendiri. Cara megatasinya mereka disuruh maju ke depan kelas untuk memimpin kegiatan tersebut.” (Wahyuni, 2020).

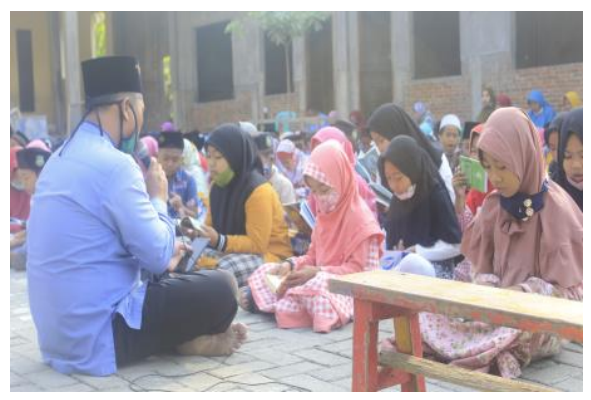

(a)

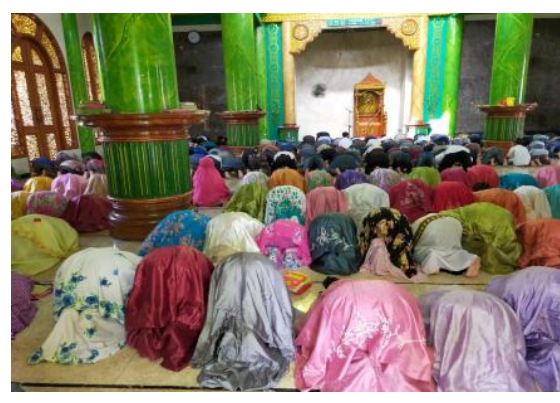

(b)

Gambar1.In (a) Kegiatan Membaca Surat Yasin; (b) Sholat Dhuha

\section{Diskusi}

Berdasarkan hasil penelitian melalui tiga teknik pengumpulan data yaitu wawancara, observasi, dan dokumentasi. Maka dilakukan analisis data menggunakan analisis data Miles dan Huberman, yang dipadukan dengan uji keabsahan data yaitu triangulasi data. Meliputi triangulasi sumber, triangulasi metode, dan triangulasi teori yang disesuaikan dengan fokus masalah penelitian.

Berdasarkan fokus masalah proses pembentukan karakter religius di Madrasah Ibtidaiyah Berbasis Pesantren di Madrasah Ibtidaiyah Miftahul Ulum Kesamben Wetan dapat ditarik hasil sebagai berikut.

1. (Andriyani, 2017). Melalui kegiatan sholat dhuha. Dengan langkah-langkah yang dilakukan pada saat awal masuk sekolah kita sudah memetakan mana anak-anak yang berangkat dari keluarga agamis dan keluarga nasionalis. Sehingga ketika kita memberikan pendekatan yang berbeda. Karakter yang terbentuk adalah kejujuran, anak-anak tidak diajarkan untuk menjadi peminta, senada dengan hasil penelitian Nuri Andriyani Penanaman Karakter Religius Melalui Pembiasaan Shalat Dhuha Di MI Ma'arif NU 1 Cilingok Kabupaten Banyumas, beliau memaparkan bahwa upaya yang dilakukan untuk membentuk karakter religius siswa 
ZAHRA: Research And Tought Elmentary School Of Islam Journal Vol. (2) (1), (Bulan)(Tahun), (Halaman)(55-72)| 63 melalui pembiasaan sholat dhuha dengan memberikan pengertian secara terus menerus tentang shalat dhuha agar siswa memiliki kesadaran untuk melaksanakan shalat dhuha.

2. Pendidikan Tahfidzul Qur'an berfungsi sebagai pembiasaan, dari kebiasaan yang dilakukan secara berulang-ulang maka anak-anak hafal ayat-ayat al-qur'an dengan sendirinya, senada dengan hasil penelitian Deddi Effendi dkk yang berjudul Impelemntasi Pendidikan Karakter Berbasis Tahfidzul Al-Qur'an, beliau mengatakan pembentukan karakter melalui Tahfidzul Al-Qur'an yang berkualitas sangat perlu dan tepat serta mudah dilakukan secara berjenjang oleh setiap lembaga secara terpadu melalui manajemen yang baik. Hal itu dibarengi dengan pembiasaan dan keteladanan yang diharapkan dapat membangun generasi Islam yang berkarakter mulia dan berbasis pada tahfidz al-Qur'an.

3. Sholat berjamaah untuk membentuk perilaku disiplin, senada dengan hasil penelitian Wuriwur gandani dkk yang berjudul Pendidikan Karakter Disiplin di Sekolah Dasar, beliau memaparkan melalui kegiatan Shalat berjamaah ini siswa dilatih untuk mematuhi aturan dalam melakukan ibadah baik mulai persiapan, pelaksanaan, hingga mengakhiri. Kegiatan Shalat berjamaah ini diwarnai dengan kebiasaan-kebiasaan yang berkaitan dengan pengkondisian siswa untuk disiplin dalam berjamaah (Wurgandi, 2014). Dan senada dengan hasil penelitian Muhamad Basori dengan Judul Kedisipilnan Shalat Berjamaah Dalam Pembinaan Akhlak Siswa Di Sekolah Menengah Atas Pondok Pesantren Modern Selamat Kendal, beliau mengatakan bahwa kedisiplinan shalat berjamaah mempunyai peran yang sangat besar dalam pembinaan perilaku siswa. Hal ini dapat dilihat dari proses kegiatan shalat berjamaah semua anggota sekolah wajib mengikuti kegiatan shalat berjamaah (Basori, 2017). Dan senada dengan hasil penelitian Uswatun Khasanah dengan judul Implementasi Pembiasaan shalat Berjamaah dalam Pembentukan Karakter Disiplin Siswa Di MI Ya BAKII Kalisabuk 02 Kecamatan Kesugihan Kabupaten Cilacap, yang menjelaskan pembiasaan shalat berjamaah dalam pembentukan karakter disiplin di MI Ya BAKII yaitu menjadikan disiplin dalam ruang lingkup disiplin waktu, tepat waktu dalam berjama'ah, tepat waktu dalam mengumandangkan adzan pada waktu shalat, tepat waktu dalam menaati peraturan, dan tepat waktu dalam berdo'a setelah shalat (Khasanah, 2017).

4. Akhlakul karimah (sikap sopan santun) untuk membentuk perilaku yang baik dalam bersikap dan bertutur kata dengan guru, orang tua ataupun dengan orang yang lebih tua, senada dengan hasil penelitian Muhamad Arif, dkk. Bahwa madrasah ibtidaiyah Miftahul Ulum adalah madrasah yang mengedepankan akhlak bagi peserta didik, sehingga madrasah ini dapat bertransfermasi sangat cepat. (Arif et al., 2020) Ernawati dalam risetnya tentang Peranan Guru Dalam Pendidikan Akhlak Di Taman Kanak-kanak Al-Qur'an Pondok Pesantren DDI Mattoanging Kecamatan Bantaeng Kabupaten Bantaeng, beliau mengatakan dalam meningkatkan pendidikan akhlak di Taman Kanak-kanak Al-Qur'an Ponpes DDI Mattoanging dengan cara memberikan contoh perilaku yang baik terhadap guru, orang tua, 
ZAHRA: Research And Tought Elmentary School Of Islam Journal Vol. (2) (1), (Bulan)(Tahun), (Halaman)(55-72)| 64 teman sejawat, orang yang lebih tua maupun muda, serta membiasakan untuk rajin membaca Al-Qur'an, dan menasehati anak ketika melakukan kesalahan (Ernawati, 2013).

5. Melalui kegiatan Idul Fitri untuk membangun karakter religius melalui kegiatan pembiasaan keagamaan, senada dengan hasil penelitian Rahma dkk yang berjudul Pembentukan Karakter Religius Siswa Melalui Pembiasaan Aktivitas Keagmaan, beliau memaparkan bahwa salah satu upaya madrasah dalam membentuk karakter religius siswa terdiri atas do'a bersama sebelum dan sesudah proses KBM, shalat dhuha dan dhuhur secara berjamaah, membaca surat-surat pendek dan asmaul husna, , berinfaq, istighasah, pembiasaan gerakan 5S (salam, senyum, sapa, sopan, santun), kegiatan ekstrakurikuler keagamaan seperti banjari, membaca dan menulis Al-Qur'an, serta Peringatan Hari Besar Islam (PHBI) yang seperti isra' mi'raj, maulid Nabi Muhammad Saw, dan Idul Qurban. Karakter religius terbentuk melalui pembiasaan aktivitas keagamaan yaitu menjalankan perintah dan menjauhi larangan Allah SWT, ikhlas, jujur, sopan santun, tolong-menolong, saling menghormati dan menghargai perbedaan, memiliki potensi yang baik, menjaga kebersihan, dan cinta rasul (Nurbaiti, 2020).

6. Melalui kegiatan pelaksanaa idul adha, anak-anak memiliki sikap menghargai satu sama lain, senada dengan pemaparan (Syamsul Hadi, 2020) yang berjudul Penyuluhan dan pembelajaran karakter melalui pelaksanaan Idul Adha pada siswa SMA, beliau mengatakan siswa lebih menghargai dan menghormati sesama siswa serta mampu menghormati guru juga orang tua ketika dirumah. Selain itu mereka memahami secara pengertian dan praktek nilainilai pengorbanan pada perayaan Idul Qurban.

7. Berbagi zakat fitrah kepada fakir miskin dibulan puasa ramadhan untuk menumbuhkan jiwa sosial anak, senada dengan pemaparan Anis Damayanti yang berjudul Pembentukan Karakter Religius Siswa Melalui Kegiatan Infak Kelas IV Di MIN 6 Ponorogo Tahun Pelajaran 2017/2018, beliau mengatakan pelaksanaan kegiatan infak dalam membentuk karakter religius siswa yakni: a) nilai ibadah terbentuk karena pengkondisian lingkungan, disini guru senantiasa menyuruh dan membiasakan anak untuk selalu berinfak sebagai wujud ibadah kepada Allah swt. b) karakter religius peduli sesama ini terbentuk karena kegiatan rutin sekolah, yaitu kegiatan yang dilakukan warga sekolah terus menerus dan tidak berubah-ubah di sekolah, seperti kegiatan ini merupakan kegiatan tetap sekolah sehingga hasilnya nanti akan digunakan menolong orang lain yang membutuhkan serta sebagai kegiatan keagamaan, disini anak akan mulai sadar untuk menolong orang lain. c) ikhlas dapat terbentuk karena pembiasaan, dengan pembiasaan berinfak maka anak-anak akan memiliki sifat yang akan dibawa hingga menjadi dewasa dan akan merasa tidak rela saat memberikan hartanya untuk orang lain (Anis, 2018). dan senada dengan pemaparan Eva Idalaila yang berjudul Pendidikan Karakter Siswa Melalui Pembiasaan Sedekah Di SMA Negeri 1 Getasan Kab. Semarang Tahun Pelajaran 2018/2019, beliau memaparkan pembiasaan sedekah 
ZAHRA: Research And Tought Elmentary School Of Islam Journal Vol. (2) (1), (Bulan)(Tahun), (Halaman)(55-72)| 65 menunjukkan adanya hasil kepada siswa yaitu sifat percaya kepada Allah, ikhlas, dan sosial yang tinggi, menghargai serta dapat menumbuhkan nilai religius, nilai kemandirian, dan nilai tanggung jawab (Ida Laila, 2019).

8. Anak-anak diajarkan berbagi pada hari Jum'at Legi. Langkah-langkah yang dilakukan dalam membentuk karakter melalui kegiatan pembiasaan dan giat pesantren. Karakter yang menonjol adalah karakter keagamaan, senada dengan pemaparan (Fifi Nofiaturrahmah, 2017) yang berjudul Penanaman Karakter Dermawan Melalui Sedekah, beliau mengatakan penanaman karakter kedermawanan melalui kegiatan infak setiap hari dan hari jum'at serta kegiatan menjenguk teman yang sakit. Kegiatan sedekah terdiri dari kegiatan berbagi kepada orang yang tidak mampu, melakukan kerja bakti dan makan makanan 4 sehat 5 sempurna bagi peserta didik. Penanaman karakter kedermawanan dilakukan dengan menggunakan cara memberikan contoh yang baik, pembiasaan, pemberian nasihat, pemantauan, dan sanksi.

9. Membaca surat yasin setiap hari jum'at dengan langkah-langkah yang digunakan melalui proses pembiasaan yang dilakukan sejak dini seperti sholat tepat waktu. Dan membentuk anak-anak yang memiliki akhlakul karimah yang baik secara religius dengan pendidikan agama dan pendidikan umum, senada dengan pemaparan Muhammad Nur Hakim yang berjudul Upaya Kepala Madrasah Dalam Membina Budaya Religius, beliau mengatakan upaya kepala madrasah yang pertama yakni pembiasaan dan mewajibkan membaca asmaul husna sebelum dimulainya kegiatan belajar yang bertempat di halaman madrasah setiap harinya, dan menghafal asmaul husna serta al-mulk ketika akan pulang sekolah. Kedua, pembiasaan membaca surat yasin pada hari jum'at, dan shalat dhuha kemudian dzuhur setiap hari sebagai penguat budaya Islam di madrasah secar berjamaah (nur Hakim, 2018). Dan senada dengan pemaparan (Akhwani dan Hanomangan Sigalingging, 2014) yang berjudul Pengembangan Karakter Religius Melalui Ekstrakurikuler Yasinan Di SMA Negeri 1 Kayen Kabupaten Pati, beliau memaparkan bahwa pengembangan karakter religius melalui ekstrakurikuler yasinan tidak semata-mata terletak pada saat membaca surat yasin tetapi melalui proses pelaksanaan kegiatan keagamaan yang biasa dilakukan, pada akhirnya dapat memunculkan sikap religious pada anggota yasinan dalam kehidupan sehari-hari. Wujud karakter religious tersebut adalah berpengetahuan tentang agama dalam berkomunikasi dan berbicara di depan uumu, taat melaksanakan ibadah sholat dhuhur berjamaah di masjid, melaksanakan sholat dhuha, sholat sunnah, berdzikir setelah sholat, terbentuk iman dan taqwa melalui keikutsertaan dalam kegiatan-kegiatan keagamaan, selalu mengingat Allah dengan berdzikir, dan berperilaku baik yang diwujudkan dalam perilaku menjenguk teman yang sakit.

10. Membaca juz amma'. Langkah-langkah yang dilakukan dengan membiasakan sholat berjamaah, mengucapkan salam dan memberi salam ketika bertemu dengan guru baik di sekolah maupun di luar sekolah. Karakter religius yang sudah terbentuk melalui proses 
ZAHRA: Research And Tought Elmentary School Of Islam Journal Vol. (2) (1), (Bulan)(Tahun), (Halaman)(55-72)| 66 pembiasaan ketika mau dan setelah makan berdo'a sendiri, ketika tiba waktu untuk pulang sekolah langsung berdo'a tanpa diberi perintah, dan ketika mendengar adzan langsung menuju ke masjid, senada dengan pemaparan Ali Mohtarom dan Wiwin Qomariyah yang berjudul Implementasi Metode Apel Dalam Menghafal Juz 'Amma Guna Meningkatkan Daya Ingat Santri Madin Children, beliau mengatakan salah satu dari penerapan metode apel yang diterapkan di Madin Children adalah apel yang diwajibkan dilaksanakan setiap hari sebelum memasuki kelas dan diikuti oleh seluruh santri, dengan tujuan membiasakan santri untuk tepat waktu pada saat memasuki kelas, yang dipimpin oleh para ustadzah secara bergantian. Hal tersebut sangat baik bagi santri yang menghafal juz 'amma', karena sudah dibaca setiap hari saat apel. Dengan begitu santri tidak merasa keberatan dalam menghafal juz 'amma mengingat usia santri yang masih dini (Mohtarom, 2016). Dan senada dengan pemaparan Lukman Hakim yang berjudul Internalisasi Nilai-nilai Agama Islam Dalam Pembentukan Sikap Dan Perilaku Siswa Sekolah Dasar Islam Terpadu Al-Muttaqin Kota Tasikmalaya, beliau mengatakan aspek nilai-nilai agama Islam yang ditanamkan di SDIT AlMuttaqin Kota Tasikmalaya meliputi: munculnya kecintaan kepada Al-Qur'an, munculnya kegiatan ibadah shalat dan berdzikir kepada Allah, kebiasaan membaca do'a sebelum melakukan kegiatan dan mengucapkan syukur sesudahnya, berpuasa di bulan ramadhan, berpakaian secara Islami, mengucapkan salam jika bertemu teman, guru, orang tua, dan saat memasuki rumah, mencuim tangan Ibu/Bapak saat hendak berangkat ke sekolah, bersikap sopan santun kepada guru, orang tua dan tetangga, menyayangi sesama manusia, memberi kepada sesama manusia yang membutuhkan, jujur, tepat waktu, kemandirian, dan bertanggung jawab (Lukman Hakim, 2012).

11. Melalui hafalan do'a sehari hari membuat anak-anak mempunyai karakter sosial, senada dengan pemaparan Nabela Lestika dkk yang berjudul Penerapan Pembiasaan Doa Bersama Sebagai Penanaman Nilai Karakter Tolernasi Dan Sosial Di SD Negeri Jatingaleh 01 Semarang, beliau mengatakan bahwa penanaman nilai karakter yang dilakukan melalui doa bersama setiap hari Rabu pagi dapat menanamkan nilai-nilai karakter yaitu perilaku menghargai seseorang dan bersikap baik kepada sesama manusia. Proses penanaman karakter tidak hanya melalui proses pembelajaran di kelas saja, akan tetapi melalui penerapan karakter peserta didik dengan pembiasaan.

Berdasarkan kendala dalam pembentukan karakter religius di Madrasah Ibtidaiyah Berbasis Pesantren Miftahul Ulum Kesamben Wetan dapat ditarik hasil sebagai berikut.

1. Kendala yang terjadi dengan mensinkronkan visi dan misi sekolah dengan yang dimau oleh orang tua. senada dengan hasil penelitian Hasan Bisri yang berjudul Kolaborasi Orang Tua Dan Guru Dalam Membentuk Karakter Disiplin Dan Jujur Pada Anak Didik (Studi Kasus Pada Siswa Kelas 3 MIN Malang2), beliau memaparkan bahwa dengan peran aktif orang tua dalam mendukung kelancaran dan kesuksesan program madrasah dan program kelas yang 
ZAHRA: Research And Tought Elmentary School Of Islam Journal Vol. (2) (1), (Bulan)(Tahun), (Halaman)(55-72)| 67 diwujudkan dalam organisasi POS (Paguyuban Orang tua Siswa) yang berpean sebagai mitra pendidikan karakter anak (Bisri, 2016). Untuk mengatasi kendala tersebut setiap kali ada pertemuan mengadakan kegiatan parenting untuk memberikan pencerahan dan pengertian agar persepsi orang tua tidak salah pemahaman dengan apa yang dilakukan pihak sekolah dalam mendidik anak-anak ketika di sekolah.(Arif \& Sulistianah, 2019) senada dengan hasil penelitian Zulkifli yang berjudul Kerjasama Sekolah dan Orang Tua dalam Menumbuhkan Karakter Siswa di SDN Lambaro Angan Aceh Besar, beliau memaparkan bentuk kerjasama sekolah dengan orang tua dalam menumbuhkan perilaku siswa dengan mengadakan rapat dengan orang tua siswa, membuat perjanjian tentang datang kesekolah tepat waktu dengan orang tua siswa, melakukan kunjungan rumah, menerima kunjungan dari orang tua siswa, melibatkan orang tua dalam menumbuhkan perilaku siswa dan mengadakan bimbingan secara khusus di sekolah (Zukfikri, 2018). dan senada dengan hasil penelitian Muammar Qadafi yang berjudul Menumbuhkan Kesadaran Orang Tua Dalam Menumbuhkan Nilai Moral Anak Usia Dini Melalui Parenting Education, yang menunjukkan bahwa program parenting cukup efektif dalam menumbuhkan kesadaran orang tua agar turut serta dalam pendidikan moral anak. Orang tua yang selalu aktif melaksanakan program-program yang telah disepakati dengan guru akan merasakan perubahan yang benar-benar nyata, baik untuk dirinya, dan juga anaknya. Sebaliknya, orang tua yang kurang aktif dapat dilihat dari kondisi anak yang tidak banyak mengalami perubahan dalam pengalaman nilai-nilai moral (Qodafi, 2019).

2. Ketika anak-anak berangkat sekolah kesiangan yang mengakibatkan tidak mau ikut sholat dhuha. senada dengan pemaparan Agus Supriyanto dal sebuah pemaparan yang berjudul Mengatasi Perilaku Terlambat Datang Ke Sekolah Melalui Layanan Konseling Individual Pendekatan Behavioristik dengan Teknik Behavior Shaping di SMP Negeri 19 Semarang Tahun ajaran 2011/2012, beliau memaparkan bahwa pelanggaran yang dilakukan siswa dengan datang terlambat datang ke sekolah dapat menghambat proses pembelajaran, siswa yang datang terlambat cenderung mengganggu teman yang lain saat pembelajaran. Kebiasaan siswa terlambat datang ke sekolah berasal dari faktor keluarga, sekolah, lingkungan, maupun pribadi siswa (Supriyanto, 2012). Cara mengatasi hal tersebut dengan memanggil anak yang bersangkutan ke kantor dan menanyakan apakah permasalahannya, agar anak-anak yang lain tidak mencontoh perilaku tersebut, senada dengan hasil penelitian (Rizki Fadliyani, 2019) yang berjudul Upaya Guru BK Dalam Mengurangi Perilaku Terlambat Siswa Dengan Menggunakan Layanan Konseling Individu Di Kelas XI MAS PAB I Sampali, beliau memaparkan upaya guru bk dalam mengurangi perilaku terlambat siswa dengan melaksanakan layanan kegiatan bimbingan secara individu dan kegiatan pendukung agar siswa dapat mencapai tujuan pendidikan. Salah satunya adalah mampu membimbing siswa untuk menjadi siswa-siswi yang disiplin. Agar mereka menyadari bahwa 
ZAHRA: Research And Tought Elmentary School Of Islam Journal Vol. (2) (1), (Bulan)(Tahun), (Halaman)(55-72)| 68 dengan menjadi disiplin akan membuat tujuan belajar yang diharapkan tercapai dan mendapatkan hasil yang maksimal.

3. Lebih telaten dalam membimbing anak-anak, senada dengan pemaparan Ahmad Hariadi dan Yanda Irawan yang berjudul Peran Guru dalam Penanaman Nilai Karakter Religius di Lingkungan Sekolah Pada Siswa Sekolah Dasar, beliau mengatakan bahwa peran guru dalam menanamkan perilaku yang berkaitan dengan ibadah diupayakan memaksimalkan peran sebagai pendidik sekaligus berperan sebagai pengajar, di dalam maupun di luar kelas dan telah memiliki kategori baik. Dengan meluangkan waktu untuk sholat berjamaah dengan tertib dan tepat waktu di mushollah, bersikap sopan dan santun saat berbicara dengan sesama peserta didik, peserta didik dengan guru, berpakaian yang menutup aurat, membiasakan senyum, sapa, dan salam (Hariadi, 2016). Dengan cara memberikan contoh yang baik dan guru tidak hanya memerintah saja tapi juga mengasih contoh seperti menyuruh anak-anak sholat dhuha berarti gurunya harus datang lebih dulu ke masjid untuk melaksanakan sholat dhuha, senada dengan pemaparan Mardiana Santi yang berjudul Kompetensi Guru dalam Meningkatkan Prestasi Belajar Siswa Di RA Al-Mujahidin Watampone Kab. Bone, beliau memaparkan bahwa guru sangat mempunyai peranan yang sangat penting dalam proses belajar mengajar disekolah bahwa guru harus mempunyai kemampuan menjadi seorang pengajar yang tidak hanya mengajar pula tetapi juga mendidik, membiasakan dan memberi contoh yang baik bagi para siswa-siswanya (Mardiana, 2011).

4. Dalam pembagian kelas, karena tidak semua anak memiliki kemampuan yang sama, senada dengan pemaparan (Dwi Faruqi, 2018) yang berjudul Upaya Meningkatkan Kemampuan Siswa Melalui Pengelolaan Kelas, beliau mengatakan bahwa kegiatan belajar mengajar terdapat dua hal yang menjadi penentuan berhasil tidaknya suatu proses pembelajaran yakni pengelolaan kelas dan proses mengajar di dalam kelas. Kedua hal itu saling berkesinambungan. Keberhasilan proses mengajar, dalam arti tercapainya keterampilan siswa yang dapat dicapai sebagai hasil belajar sangat bergantung pada kemampuan mengelola kelas. Kelas yang baik dapat menciptakan situasi yang memungkinkan siswa belajar dengan semangat sehingga merupakan titik awal keberhasilan pembelajaran. Untuk mengatasinya maka kita sebagai seorang guru harus terus bersabar dan telaten, senada dengan (Elly Manizar, 2015) yang berjudul Peran Guru Sebagai Motivator Dalam Belajar, beliau memaparkan bahwa langkah-langkah yang dilakukan untuk menumbuhkan motivasi belajar siswa dengan bersikap terbuka, membimbing siswa untuk mau memahami dan memanfaatkan potensi dalam diri, menciptakan hubungan yang serasi, serta merangsang keaktifan para siswa.

5. Anak-anak tidak mau mengikuti kegiatan yang diperintahkan oleh gurunya., senada dengan pemaparan (Moch. Sya'roni dan Hanifa Rusydiana, 2018) dengan judul Penerapan Sanksi Eduaktif Dalam Peningkatan Kedisiplinan Peserta didik Di MTS Semesta Kedungmaling 
ZAHRA: Research And Tought Elmentary School Of Islam Journal Vol. (2) (1), (Bulan)(Tahun), (Halaman)(55-72)| 69 Sooko Mojokerto, beliau mengatakan penerapan sanksi edukatif bisa dilakukan dengan cara sosialisasi, pada tahap ini pihak madrasah mengundang orang tua siswa untuk menandatangani MoU (Memorandum of Understanding) tentang aturan tata tertib yang diterapkan di sekolah dan hukuman yang diberikan. Selain itu peserta didik diberikan arahan yang baik di dalam kelas maupun ketika salam pagi dan salam siang. Untuk mengatasinya dengan menyuruh mereka maju kedepan kelas untuk memimpin kegiatan tersebut, senada dengan hasil penelitian Nurur Rohman yang berjudul Peran Guru Dalam Memebntuk Sikap Disiplin Kelas V Di MIN Jombang, beliau memaparkan bahwa guru berperan sebagai pemberi arahan, contohnya guru memberi arahan kepada siswa jika melakukan kesalahan yaitu dengan cara memberi peringatan, dan guru memberi arahan kepada siswa berupa pemberian sanksi jika tidak melaksanakan sesuai dengan aturan (Rohman, 2019).

\section{Simpulan}

Berdasarkan fokus masalah peneliti yaitu, bagaimana proses pembentukan karakter religius di Madrasah Ibtidaiyah Berbasis Pesantren dan apa saja kendala dalam pembentukan karakter religius di Madrasah Ibtidaiyah Berbasis Pesantren Miftahul Ulum Kesamben Wetan mendapatkan hasil sebagai berikut: Proses pembentukan karakter religius di Madrasah Ibtidaiyah Berbasis Pesantren Miftahul Ulum Kesamben Wetan yaitu: a. Melalui kegiatan sholat dhuha, dengan langkah-langkah yang dilakukan pada saat awal masuk sekolah kita sudah memetakan mana anak-anak yang berangkat dari keluarga agamis dan keluarga nasionalis. Sehingga ketika kita memberikan pendekatan yang berbeda. Karakter yang terbentuk adalah kejujuran, anak-anak tidak diajarkan untuk menjadi peminta. b. Pendidikan Tahfidzul Qur'an berfungsi sebagai pembiasaan, dari kebiasaan yang dilakukan secara berulang-ulang untuk memudahkan siswa menghafal ayat-ayat al-qur'an. c. Sholat berjamaah untuk membentuk perilaku disiplin. d. Akhlakul karimah (sikap sopan santun) untuk membentuk perilaku yang baik dalam bersikap dan bertutur kata dengan orang tua, guru ataupun dengan orang yang lebih tua. e. Melalui kegiatan Idul Fitri untuk membangun karakter religius melalui kegiatan pembiasaan keagamaan. f. Melalui kegiatan pelaksanaa idul adha, anak-anak memiliki sikap mengharhai satu sama lain. g. Berbagi zakat fitrah kepada fakir miskin dibulan puasa ramadhan untuk menumbuhkan jiwa sosial anak. h. Anak-anak diajarkan berbagi pada Jum'at Legi. Langkah-langkah yang dilakukan dalam membentuk karakter melalui kegiatan pembiasaan dan giat pesantren. Karakter yang menonjol adalah karakter keagamaan. i. Membaca surat yasin setiap Jum'at dengan langkah-langkah yang digunakan melalui proses pembiasaan yang dilakukan sejak dini seperti sholat tepat waktu. Dan membentuk akhlakul karimah pada peserta didik secara religius dengan pendidikan agama dan pendidikan umum. j. Membaca juz amma'. Langkah-langkah yang dilakukan dengan membiasakan sholat berjamaah, mengucapkan salam dan memberi salam ketika bertemu dengan guru baik di dalam ataupun di luar sekolah. Karakter religius yang sudah terbentuk melalui proses pembiasaan ketika mau dan setelah makan berdo'a sendiri, ketika tiba waktu untuk pulang sekolah langsung berdo'a 
ZAHRA: Research And Tought Elmentary School Of Islam Journal Vol. (2) (1), (Bulan)(Tahun), (Halaman)(55-72)| 70 tanpa diberi perintah, dan ketika mendengar adzan langsung menuju ke masjid. k. Melalui hafalan do’a sehari-hari membuat anak-anak mempunyai karakter sosial.

Kendala yang dihadapi dalam pembentukan karakter religius di Madrasah Ibtidaiyah Berbasis Pesantren Miftahul Ulum Kesamben Wetan yaitu: a. mensinkronkan visi dan misi sekolah dengan yang dimau oleh orang tua. Untuk mengatasi kendala tersebut setiap kali ada pertemuan kita adakan kegiatan parenting untuk memberikan pencerahan dan pengertian agar persepsi orang tua tidak salah pemahaman dengan apa yang dilakukan pihak sekolah dalam mendidik anak-anak ketika di sekolah. b. Ketika anak-anak berangkat sekolah kesiangan yang mengakibatkan tidak mau ikut sholat dhuha. Cara mengatasi hal tersebut dengan memanggil anak yang bersangkutan ke kantor dan menanyakan apakah permasalahannya, agar anak-anak yang lain tidak mencontoh perilaku tersebut. c. Lebih telaten dalam membimbing anak-anak, dengan memberikan contoh yang baik dan guru tidak hanya memerintah saja tapi juga mengasih contoh seperti menyuruh anak-anak sholat dhuha berarti gurunya harus datang lebih dulu ke masjid untuk melaksanakan sholat dhuha. d. Dalam pembagian kelas, karena tidak semua anak memiliki kemampuan yang sama, maka kita sebagai seorang guru harus terus bersabar dan telaten. e. Anak-anak tidak mau mengikuti kegiatan yang diperintahkan oleh gurunya. Dengan menyuruh mereka maju kedepan kelas untuk memimpin kegiatan tersebut.

\section{Daftar Pustaka}

Azizah, Tsalis Nurul. (2017). Pembentukan Karakter Religius Berbasis Pembiasaan dan Keteladanan di SMA Sains Al-Qur'an Wahid Hasyim Yogyakarta (Skripsi). UIN Sunan Kalijaga Yogyakarta, Yogyakarta.

Akhwani dan Hanomangan Sigalingging. (2014). Pengembangan Karakter Religius Melalui Ekstrakurikuler Yasinan Di SMA Negeri 1 Kayen. Unnes Civic Education Journal, Vol. 3, No. 1, 11-17. http://journal.unnes.ac.id/sju/index.php.ucej

Andriyani, Nuri. (2017). Penanaman Karakter Religius Melalui Pembiasaan Shalat Dhuha Di MI Ma'arif NU 1 Cilingok Kabupaten Banyumas. (Skripsi). IAIN Purwokerto.

Arif, M., \& Handayani, E. F. (2020). Budaya Literasi Madrasah Ibtidaiyah. MODELING: Jurnal Program Studi PGMI, 7(2), 198-220.

Arif, M., \& Sulistianah, S. (2019). Problems in 2013 Curriculum Implementation for Classroom Teachers in Madrasah Ibtidaiyah. Al Ibtida: Jurnal Pendidikan Guru MI, 6(1), 110. https://doi.org/10.24235/al.ibtida.snj.v6i1.3916

Arif, M., Bahrozi, I., \& Hudah, N. (2020). Madrasah Ibtidaiyah Transformation Based on Pesantren in the Era of Industrial Revolution 4.0. Psychology and Education, 57(8), 420-435.

Basori, Muhamad. (2017). Kedisipilnan Shalat Berjamaah Dalam Pembinaan Akhlak Siswa Di Sekolah Menengah Atas Pondok Pesantren Modern Selamat Kendal. Skripsi. UIN Walisongo Semarang.

Bisri, Hasan. (2016). Kolaborasi Orang Tua Dan Guru Dalam Membentuk Karakter Disiplin Dan Jujur Pada Anak Didik (Studi Kasus Pada Siswa Kelas 3 MIN Malang2) (Tesis). UIN Maulana Malik Ibrahim Malang.

Chasanah, Uswatun. (2011). Model Pendidikan Berbasis Karater di Sekolah Dasar Al-Azhar Kepala Gading Surabaya (Tesis). Insitut Agama Islam Sunan Ampel Surabaya.

Damayanti, Anis. (2018). Pembentukan Karakter Religius Siswa Melalui Kegiatan Infak Kelas IV Di MIN 6 Ponorogo Tahun Pelajaran 2017/2018 (Skripsi). IAIN Ponorogo. 
ZAHRA: Research And Tought Elmentary School Of Islam Journal Vol. (2) (1), (Bulan)(Tahun), (Halaman)(55-72)| 71

Effendi, Deddi, dkk. Impelemntasi Pendidikan Karakter Berbasis Tahfidzul Al-Qur'an. http://pkm.uika-bogor.ac.id/index.php/PSBKI/article/download/123

Ernawati, E. (2013). Peranan Guru Dalam Pendidikan Akhlak Di Taman Kanak-kanak Al-Qur'an Pondok Pesantren DDI Mattoanging Kecamatan Bantaeng Kabupaten Bantaeng (Skripsi). UIN Alauddin Makasar.

Fadliyani, Rizki. (2019). Upaya Guru BK Dalam Mengurangi Perilaku Terlambat Siswa Dengan Menggunakan Layanan Konseling Individu Di Kelas XI MAS PAB I Sampali (Skripsi). UIN Sumatera Utara Medan.

Faruqi, Dwi. (2018). Upaya Meningkatkan Kemampuan Belajar Siswa Melalui Pengelolaan Kelas,” Jurnal Manajemen Pendidikan Islam, Vol.2, No.1, 294-310. https://e-journal.staimaalhikam.ac.id/evaluasi/articel/view/80/85

Hakim, Lukman. (2012). Internalisasi Nilai-nilai Agama Islam Dalam Pembentukan Sikap Dan Perilaku Siswa Sekolah Dasar Islam Terpadu Al-Muttaqin Kota Tasikmalaya. Jurnal Pendidikan Agama Islam-Ta'lim, Vol.10, $\quad$ No. 1, 67-77. http://jurnal.upi.edu/file/5_Penanaman_Nilai.pdf\&ved=2ahUKEwjqgpndj4

Hakim, Muhammad Nur. (2018). Upaya Kepala Madrasah Dalam Membina Budaya Religius,” Jurnal Improvement, Vol.5, No.1, 74-88. http://journal.uni.ac.id/unj/index.php/improvement

Hambali, Muh, dan Eva Yulianti. (2018). Ekstrakurikuler Keagamaan Terhadap Pembentukan Karakter Religius Peserta Didik di Kota Majapahit. Jurnal Pedagogik Vol.05, No.02, 193208. https://ejournal.unuja.ac.id/index.php/pedagogik

Hariadi, Ahmad dan Yanda Irawan. (2016). Peran Guru dalam Penanaman Nilai Karakter Religius di Lingkungan Sekolah Pada Siswa Sekolah Dasar," JURNAL GENTALA PENDIDIKAN DASAR, Vol.1, No.1, 176-189. http://online-journal.unja.ac.id/index.php/gentala

Idalaila, Eva. (2019). Pendidikan Karakter Siswa Melalui Pembiasaan Sedekah Di SMA Negeri 1 Getasan Kab. Semarang Tahun Pelajaran 2018/2019. (Skripsi), IAIN Salatiga.

Jannah, Miftahul. (2019). Metode dan Strategi Pembentukan Karakter Religius yang diterapkan di SDTQ An-Najah Pondok Pesantren Cindai Alus Martapura. Jurnal Ilmiah Pendidikan Madrasah Ibtidiyah, Vol.4, No. 1, 77-102. https://jurnal.stiq-amuntai.ac.id/index.php/almadrasah/articel/download

Kesuma, Dharman., Trianti, Cepi., dan Pernama, Johar. (2018). Pendidikan Karakter Kajian Teori dan Praktik di Sekolah. Bandung: PT Remaja Rosdakarya.

Khasanah, Uswatun. (2017). Implementasi Pembiasaan shalat Berjamaah dalam Pembentukan Karakter Disiplin Siswa Di MI Ya BAKII Kalisabuk 02 Kecamatan Kesugihan Kabupaten Cilacap (Skripsi). IAIN Purwokerto.

Lestika, Nabela, dkk. Penerapan Pembiasaan Doa Bersama Sebagai Penanaman Nilai Karakter Tolernasi Dan Sosial Di SD Negeri Jatingaleh 01 Semarang. http://conference.upgris.ac.id/index.php/sendika/article/downdload

Manizar, Elly. (2015). Peran Guru Sebagai Motivator Dalam Belajar. Tadrib, Vol.1, No.2 (2015):118. http://jurnal.radenfatah.ac.id/index.php/Tadrib/article/download/1047

Marzuki. M. 2015. Pendidikan Karakter Islam. Jakarta: Amzah.

Mohtarom, Ali dan Wiwin Qomariyah. (2016). Implementasi Metode Apel Dalam Menghafal Juz 'Amma Guna Meningkatkan Daya Ingat Santri Madin Children. al-Murabbi, Vol.1, No. 1, 31-54. http://download.garuda.ristekdikti.go.id/article.php\%3Farticle\%3D899080

Nasrullah, Muhammad Haris. Pendidikan Karakter Religius Pada Sekolah Berbasis Pesantren (Studi pada SMA Al-Muayyad Mangkuyudan Surakarta) (SKRIPSI). UIN Walisongo Semarang, Jawa Tengah. 
ZAHRA: Research And Tought Elmentary School Of Islam Journal Vol. (2) (1), (Bulan)(Tahun), (Halaman)(55-72)| 72 Nofiaturrahmah, Fifi. (2017). Penanaman Karakter Dermawan Melalui Sedekah,” Jurnal Zakat dan Wakaf, Vol.4, No.2, 313-326. https://journal.iainkudus.ac.id/index.php/Ziswaf/article

Nurbaiti, Rahma, dkk. (2020). Pembentukan Karakter Religius Siswa Melalui Pembiasaan Aktivitas Keagamaan. Journal of Islamic Elementary Education, Vol.2, No.1, 55-65. https://ejournal.iai-tribakti.ac.id/index.php/pgmi

Nurul, M. Huda. (2019). Pembentukan Karakter Religius Melalui Pendidikan Pencak Silat (Studi Multi Kasus Persaudaraan Setia Hati Terate di Smp Bahrul Ulum Putat Jaya dan Pagar Nusa di Smp Khm Nur Karang Tembok Surabaya) (Tesis). UIN Sunan Ampel Surabaya, Jawa Timur.

Oktari, Dian Popi dan Aceng. (2019). Pendidikan Karakter Religius dan Mandiri di Pesantren. Jurnal Pendidikan Ilmu Islam, $\quad$ Vol.28, https://ejournal.upi.edu/index.php.jpis/article/view/14985

Qadafi, Muammar. (2019). Menumbuhkan Kesadaran Orang Tua Dalam Menumbuhkan Nilai Moral Anak Usia Dini Melalui Parenting Education," Jurnal Pendidikan Anak Usia dini, Vol.4, No.1, 57-65. http://ejournal.ihdn.ac.id/index.php/PW/article/view/1069

Rohman, Nurur. (2019). Peran Guru Dalam Memebntuk Sikap Disiplin Kelas V Di MIN Jombang (Skripsi). UIN Maulana Malik Ibrahim.

Rosyidah, Happy Makrufiati. (2019). Strategi Pembentukan Karakter Religius Melalui Program Madrasah Ibtidiyah Taklimiyah di SMP Islam Hasanudin Kesamben Kabupaten Blitar (Tesis). UIN Maulana Malik Ibrahim Malang, Jawa Timur.

Santi,Mardiana. (2011). Kompetensi Guru dalam Meningkatkan Prestasi Belajar Siswa Di RA AlMujahidin Watampone Kab. Bone (Skripsi). UIN Alauddin Makassar.

Supriyanto, Agus. (2012). Mengatasi Perilaku Terlambat Datang Ke Sekolah Melalui Layanan Konseling Individual Pendekatan Behavioristik dengan Teknik Behavior Shaping di SMP Negeri 19 Semarang Tahun ajaran 2011/2012. Indonesian Journal of Guidence and Conseling, Vol.1, No. 01, 37-42. http://journal.unnes.ac.id/sju/index.php/jbk

Sya'roni Moch. dan Hanifa Rusydiana. (2018). Penerapan Sanksi Eduaktif Dalam Peningkatan Kedisiplinan Peserta didik Di MTS Semesta Kedungmaling Sooko Mojokerto. Jurnal Studi Keislaman, Vol.4, No.2, 151-178. https://media.neliti.com/media/publication/291586penerapan

Syamsul Hadi, dkk. (2020). Penyuluhan dan pembelajaran karakter melalui pelaksanaan Idul Adha pada siswa SMA. Jurnal Pemberdayaan, Vol.4, No.2, 205-210. http://journal2.uad.ac.id/index.php./jpmuad/articel/download

Wurgandi, Wuri, ddk. (2014). Pendidikan Karakter Disiplin di Sekolah Dasar. Cakrawala Pendidikan, $\begin{array}{llll}\text { Th. XXXIII } & \text { No. 286-295. }\end{array}$ https://stafnew.uny.ac.id/upload/132309073/penelitian/pendidikan

Zulkifli. (2018). Kerjasama Sekolah dan Orang Tua dalam Menumbuhkan Karakter Siswa di SDN Lambaro Angan Aceh Besar (Skripsi). UIN Ar-Raniry Darussalam Banda Aceh. 